\title{
The Most Frequently Read Articles of 2020
}

\author{
Phil Lupo, MLIS, Marjorie A. Bowman, MD, MPA, Dean Seebusen, MD, MPH, and \\ Christy J. W. Ledford, PhD
}

\section{( J Am Board Fam Med 2021;34:462-465.)}

2020 was the $33^{\text {rd }}$ year of print and $18^{\text {th }}$ year of online publication of the Fournal of the American Board of Family Medicine ( $7 A B F M)$. Here we provide our annual report of articles published in 2020 that were of greatest interest to our readers. Table 1 shows the 3 most frequently read articles by issue in 2020 from Volume 33. Once again, original research proves to be the most-read type of article. Glucosamine/ Chondroitin and Mortality in a US NHANES Cohort by King and Xiang ${ }^{1}$ was the most read article in 2020 from Volume 33. In Table 2, we provide the 20 most frequently read articles in 2020 from all volumes (Volume 1 to 33). Historically, clinical articles tend to be the most read.

As always, we welcome reader feedback about published articles. Letters to the editor can also be submitted for peer review and publication using the author portal.

To see this article online, please go to: http://jabfm.org/content/ 34/3/462.full.

\section{References}

1. King DE, Xiang J. Glucosamine/chondroitin and mortality in a US NHANES cohort. J Am Board Fam Med 2020;33:842-7.

2. Redinger $M$, Fledderman N, Crutchfield P. An ethical framework to manage patient requests for medical marijuana. J Am Board Fam Med 2020;33: $147-51$.

3. Sokol R, Schuman-Olivier Z, Batalden M, Sullivan L, Shaughnessy AF. A change management case study for safe opioid prescribing and opioid use disorder treatment. J Am Board Fam Med 2020;33: $129-37$.

4. Johnson MS. Family medicine and the "new" opioid epidemic. J Am Board Fam Med 2020;33:1-3.

5. Kaplan AG. Inhaled corticosteroid treatment in chronic obstructive pulmonary disease (COPD):

Conflicts of interest: The authors are editors of the $7 A B F M$. boon or bane? J Am Board Fam Med 2020;33: 289-302.

6. McCormick JR, Sama AJ, Schiller NC, Butler AJ, Donnally CJ., III,. Cervical spondylotic myelopathy: a guide to diagnosis and management. J Am Board Fam Med 2020;33:303-13.

7. Sullivan HW, Aikin KJ, Berktold J, Stein KL, Hoverman VJ. Direct-to-consumer prescription drug advertising and patient-provider interactions. J Am Board Fam Med 2020;33:279-83.

8. Goetz Goldberg D, Soylu TG, Grady VM, Kitsantas P, Grady JD, Nichols LM. Indicators of workplace burnout among physicians, advanced practice clinicians, and staff in small to mediumsized primary care practices. J Am Board Fam Med 2020;33:378-85.

9. Ludden T, Shade L, Thomas J, et al. Novel models to identify census tracts for hepatitis C screening interventions. J Am Board Fam Med 2020;33: 407-16.

10. Gold KJ. Women's work: why are women physicians more burned out? J Am Board Fam Med 2020;33:351-4.

11. Fleming P, Yang YB, Lynde C, O’Neill B, Lee KO. Diagnosis and management of atopic dermatitis for primary care providers. J Am Board Fam Med 2020;33:626-35.

12. Stack M, LaRouche V, Zhang Y, Warden D, Stack C, Klugiene EA. Effects of implementing a comprehensive opioid reduction protocol on overall opioid prescribing among patients with chronic, non-cancer pain in a rural family medicine clinic: a controlled cross-over trial. J Am Board Fam Med 2020;33:502-11.

13. Spithoff S, Mathieson S, Sullivan F, et al. Clinical decision support systems for opioid prescribing for chronic non-cancer pain in primary care: a scoping review. J Am Board Fam Med 2020;33:529-40.

14. Akiki RK, Mehrzad R. Practical management of common skin injuries, lacerations, wounds, trigger fingers, and burns. J Am Board Fam Med 2020;33:799-808.

15. Norton MC, Haftman ME, Buzzard LN. Impact of physician-pharmacist collaboration on diabetes outcomes and health care use. J Am Board Fam Med 2020;33:745-53. 
Table 1. The Three Most Frequently Read Articles in the Journal of the American Board of Family Medicine, 2020, Volume 33, by Issue*

January/February 2020

1. An Ethical Framework to Manage Patient Requests for Medical Marijuana. ${ }^{2}$

Ethics Feature: https://www.jabfm.org/content/33/1/147

2. A Change Management Case Study for Safe Opioid Prescribing and Opioid Use Disorder Treatment. ${ }^{3}$ Special Communication: https://www.jabfm.org/content/33/1/129

3. Family Medicine and the "New" Opioid Epidemic. ${ }^{4}$

Commentary: https://www.jabfm.org/content/33/1/1

March/April 2020

1. Inhaled Corticosteroid Treatment in Chronic Obstructive Pulmonary Disease (COPD): Boon or Bane? ${ }^{5}$

Clinical Review: https://www.jabfm.org/content/33/2/289

2. Cervical Spondylotic Myelopathy: A Guide to Diagnosis and Management. ${ }^{6}$

Clinical Review: https://www.jabfm.org/content/33/2/303

3. Direct-to-Consumer Prescription Drug Advertising and Patient-Provider Interactions.

Brief Report: https://www.jabfm.org/content/33/2/279

May/June 2020

1. Indicators of Workplace Burnout Among Physicians, Advanced Practice Clinicians, and Staff in Small to Medium-Sized Primary Care Practices. ${ }^{8}$

Original Research: https://www.jabfm.org/content/33/3/378

2. Novel Models to Identify Census Tracts for Hepatitis C Screening Interventions. ${ }^{9}$

Original Research: https://www.jabfm.org/content/33/3/407

3. Women's Work: Why Are Women Physicians More Burned Out? ${ }^{10}$

Commentary: https://www.jabfm.org/content/33/3/351

July/August 2020

1. Diagnosis and Management of Atopic Dermatitis for Primary Care Providers. ${ }^{11}$

Clinical Review: https://www.jabfm.org/content/33/4/626

2. Effects of Implementing a Comprehensive Opioid Reduction Protocol on Overall Opioid Prescribing Among Patients with Chronic, Non-Cancer Pain in a Rural Family Medicine Clinic: A Controlled Cross-over Trial. ${ }^{12}$

Original Research: https://www.jabfm.org/content/33/4/502

3. Clinical Decision Support Systems for Opioid Prescribing for Chronic Non-Cancer Pain in Primary Care: A Scoping Review. ${ }^{13}$

Original Research: https://www.jabfm.org/content/33/4/529

September/October 2020

1. Practical Management of Common Skin Injuries, Lacerations, Wounds, Trigger Fingers, and Burns. ${ }^{14}$ Clinical Review: https://www.jabfm.org/content/33/5/799

2. Impact of Physician-Pharmacist Collaboration on Diabetes Outcomes and Health Care Use. ${ }^{15}$

Original Research: https://www.jabfm.org/content/33/5/745

3. Identifying Practice Facilitation Delays and Barriers in Primary Care Quality Improvement. ${ }^{16}$

Original Research: https://www.jabfm.org/content/33/5/655

September Supplement 2020

1. How Should Board Certification Evolve? ${ }^{17}$

Article: https://www.jabfm.org/content/33/Supplement/S1

2. The Role of Certifying Boards in Improving Health: The Example of the American Board of Pediatrics. ${ }^{18}$ Commentary: https://www.jabfm.org/content/33/Supplement/S36

3. Connecting Purpose and Performance: Rethinking the Purpose of Maintenance of Certification. ${ }^{19}$

Commentary: https://www.jabfm.org/content/33/Supplement/S15

November/December 2020

1. Glucosamine/Chondroitin and Mortality in a US NHANES Cohort. ${ }^{1}$

Original Research: https://www.jabfm.org/content/33/6/842

2. Current Indications for Tonsillectomy and Adenoidectomy. ${ }^{20}$

Evidence-Based Clinical Medicine: https://www.jabfm.org/content/33/6/1025

3. Association of Patient-Provider Teach-Back Communication with Diabetic Outcomes: A Cohort Study. ${ }^{21}$ Original Research: https://www.jabfm.org/content/33/6/903

*Content usage statistics for the $7 A B F M$, January 2020 through December 2020, HighWire Press. Accessed March 5, 2021. Rankings are updated monthly and based on 'hits' received by articles archived on the FABFM website only. 
1. Approach to Leg Edema of Unclear Etiology.22

Evidence-Based Clinical Medicine: https://www.jabfm.org/content/19/2/148

2. Novel Treatment of Onychomycosis using Over-the-Counter Mentholated Ointment: A Clinical Case Series. ${ }^{23}$

Original Research: https://www.jabfm.org/content/24/1/69

3. High-Rising Epiglottis in Children: Should It Cause Concern? ${ }^{24}$

Brief Report: https://www.jabfm.org/content/20/5/495

4. Validation of the Insomnia Severity Index in Primary Care. ${ }^{25}$

Original Research: https://www.jabfm.org/content/26/6/701

5. When Is Fluid in the Mastoid Cells a Worrisome Finding? ${ }^{26}$

Brief Report: https://www.jabfm.org/content/26/2/218

6. Treatment of Acne in Pregnancy. ${ }^{27}$

Clinical Review: https://www.jabfm.org/content/29/2/254

7. Glucosamine/Chondroitin and Mortality in a US NHANES Cohort. ${ }^{1}$

Original Research: https://www.jabfm.org/content/33/6/842

8. Split Peroneus Brevis Tendon: An Unusual Cause of Ankle Pain and Instability. ${ }^{28}$ Brief Report: https://www.jabfm.org/content/27/2/297

9. A Qualitative Study of Depression in Primary Care: Missed Opportunities for Diagnosis and Education. ${ }^{29}$ Original Research: https://www.jabfm.org/content/20/1/28

10. Early Diagnosis and Treatment of Discoid Lupus Erythematosus. ${ }^{30}$ Brief Report: https://www.jabfm.org/content/22/2/206

11. Cotton Fever: A Condition Self-Diagnosed by IV. Drug Users. ${ }^{31}$ Brief Report: https://www.jabfm.org/content/29/2/276

12. Healthy Lifestyle Habits and Mortality in Overweight and Obese Individuals. ${ }^{32}$ Original Research: https://www.jabfm.org/content/25/1/9

13. Socioeconomic Status and Other Factors Associated with Childhood Obesity. ${ }^{33}$ Original Research: https://www.jabfm.org/content/31/4/514

14. Left-Sided Leg Edema Of The Elderly: A Common Variant Of The Iliac Compression Syndrome. ${ }^{34}$ Original Article: https://www.jabfm.org/content/jabfp/6/1/1.full.pdf

15. Secondary Hyperparathyroidism: Pathophysiology and Treatment. ${ }^{35}$ Clinical Review: https://www.jabfm.org/content/22/5/574

16. Soil-Related Bacterial and Fungal Infections. ${ }^{36}$ Clinical Review: https://www.jabfm.org/content/25/5/734

17. Intersection Syndrome: The Subtle Squeak of an Overused Wrist. ${ }^{37}$ Brief Report: https://www.jabfm.org/content/30/4/547

18. Diagnosis and Management of Acute Coronary Syndrome: An Evidence-Based Update. ${ }^{38}$ Clinical Review: https://www.jabfm.org/content/28/2/283

19. Staphylococcus epidermidis in Urine Is Not Always Benign: A Case Report of Pyelonephritis in a Child. ${ }^{39}$ Brief Report: https://www.jabfm.org/content/28/1/151

20. Dry Needling in the Management of Musculoskeletal Pain. ${ }^{40}$ Clinical Review: https://www.jabfm.org/content/23/5/640

${ }^{*}$ Content usage statistics for the $7 A B F M$, January 2020 through December 2020, HighWire Press. Accessed March 5, 2021. Rankings are updated monthly and based on 'hits' received by articles archived on the FABFM website only.

16. Ye J, Zhang R, Bannon JE, et al. Identifying practice facilitation delays and barriers in primary care quality improvement. J Am Board Fam Med 2020;33:655-64.

17. Newton WP. How should board certification evolve? J Am Board Fam Med 2020;33:S1-S9.

18. Lannon C, Nichols DG. The role of certifying boards in improving health: the example of the American Board of Pediatrics. J Am Board Fam Med 2020;33:S36-S41.

19. Harman AE, Warner DO, Cole DJ. Connecting purpose and performance: rethinking the purpose of maintenance of certification. J Am Board Fam Med 2020;33:S15-S20.

20. Randall DA. Current indications for tonsillectomy and adenoidectomy. J Am Board Fam Med 2020;33:1025-30.

21. Hong Y-R, Huo J, Jo A, Cardel M, Mainous AG, 3rd. Association of patient-provider teach-back communication with diabetic outcomes: a cohort study. J Am Board Fam Med 2020;33:903-12.

22. Ely JW, Osheroff JA, Chambliss ML, Ebell MH. Approach to leg edema of unclear etiology. J Am Board Fam Med 2006;19:148-60. 
23. Derby R, Rohal P, Jackson C, Beutler A, Olsen C. Novel treatment of onychomycosis using over-thecounter mentholated ointment: a clinical case series. J Am Board Fam Med 2011;24:69-74.

24. Petkar N, Georgalas C, Bhattacharyya A. High-rising epiglottis in children: should it cause concern? J Am Board Fam Med 2007;20:495-6.

25. Gagnon C, Bélanger L, Ivers H, Morin CM. Validation of the Insomnia Severity Index in primary care. J Am Board Fam Med 2013;26:701-10.

26. McDonald MH, Hoffman MR, Gentry LR. When is fluid in the mastoid cells a worrisome finding? J Am Board Fam Med 2013;26:218-20.

27. Chien AL, Qi J, Rainer B, Sachs DL, Helfrich YR. Treatment of acne in pregnancy. J Am Board Fam Med 2016;29:254-62.

28. Chauhan B, Panchal P, Szabo E, Wilkins T. Split peroneus brevis tendon: an unusual cause of ankle pain and instability. J Am Board Fam Med 2014;27:297-302.

29. Saver BG, Van-Nguyen V, Keppel G, Doescher MP. A qualitative study of depression in primary care: missed opportunities for diagnosis and education. J Am Board Fam Med 2007;20:28-35.

30. Panjwani S. Early diagnosis and treatment of discoid lupus erythematosus. J Am Board Fam Med 2009;22:206-13.

31. Zerr AM, Ku K, Kara A. Cotton fever: a condition self-diagnosed by IV drug users. J Am Board Fam Med 2016;29:276-9.
32. Matheson EM, King DE, Everett CJ. Healthy lifestyle habits and mortality in overweight and obese individuals. J Am Board Fam Med 2012;25:9-15.

33. Williams AS, Ge B, Petroski G, Kruse RL, McElroy JA, Koopman RJ. Socioeconomic status and other factors associated with childhood obesity. J Am Board Fam Med 2018;31:514-21.

34. Sloane PD, Baldwin R, Montgomery R, Hargett F, Hartzema A. Left-sided leg edema of the elderly: a common variant of the iliac compression syndrome. J Am Board Fam Pract 1993;6:1-4.

35. Saliba W, El-Haddad B. Secondary hyperparathyroidism: pathophysiology and treatment. J Am Board Fam Med 2009;22:574-81.

36. Baumgardner DJ. Soil-related bacterial and fungal infections. J Am Board Fam Med 2012;25:734-44.

37. Skinner TM. Intersection syndrome: the subtle squeak of an overused wrist. J Am Board Fam Med 2017;30:547-51.

38. Smith JN, Negrelli JM, Manek MB, Hawes EM, Viera AJ. Diagnosis and management of acute coronary syndrome: an evidence-based update. J Am Board Fam Med 2015;28:283-93.

39. Lozano V, Fernandez G, Spencer PL, Taylor SL, Hatch R. Staphylococcus epidermidis in urine is not always benign: a case report of pyelonephritis in a child. J Am Board Fam Med 2015;28:151-3.

40. Kalichman L, Vulfsons S. Dry needling in the management of musculoskeletal pain. J Am Board Fam Med 2010;23:640-6. 